\title{
Tree-ring $\Delta^{13} \mathrm{C}$ reveals the impact of past forest management on water-use efficiency in a Mediterranean oak coppice in Tuscany (Italy)
}

\author{
Giovanni Di Matteo ${ }^{1,2} *$, Paolo De Angelis ${ }^{1}$, Enrico Brugnoli ${ }^{3}$, Paolo Cherubini ${ }^{4}$, \\ Giuseppe ScARASCIA-MUGNOZZA ${ }^{1}$
}

\author{
${ }^{1}$ DISAFRI - Department of Forest Environment and Resources, University of Tuscia, via San Camillo de Lellis s.n.c., 01100, Viterbo, Italy \\ ${ }^{2}$ CRA - Research Unit for Wood Production Outside Forests, via Valle della Quistione 27, 00166 Rome, Italy \\ ${ }^{3}$ CNR - Institute of Agro-Environmental and Forest Biology, via Guglielmo Marconi 2, 05010 Porano (TR), Italy \\ ${ }^{4}$ WSL - Swiss Federal Institute for Forest, Snow and Landscape Research, Zurcherstrasse 111, 8903 Birmensdorf, Switzerland
}

(Received 19 May 2009; accepted 17 October 2009)

Keywords:

Quercus cerris /

carbon isotopes /

tree-rings /

basal area increment /

silvicultural treatments /

abandoned coppices

\begin{abstract}
- The effects of thinning and heavy stand density reduction was investigated in Turkey oak (Quercus cerris L.) forests of central Italy, to evaluate the physiological responses and the growth status of trees that survived a past coppice cut and thinning to convert the stand to high-forest.

- The working hypothesis was that a strong decrease in stand density would cause a decreasing in canopy-intrinsic water-use efficiency (measured as the ratio of $\mathrm{CO}_{2}$ assimilation to stomatal conductance, $A / g)$, thus an increase in tree-ring carbon isotopic discrimination $\left(\Delta^{13} \mathrm{C}\right)$.

- The tree-ring $\Delta^{13} \mathrm{C}$ of the remaining trees ("survivors") was found to have significantly $(P<0.05)$ raised between year two and year seven since the coppice stand was thinned (high-forest conversion thinnings). This effect was mostly caused by a large decrease in tree-rings $\Delta^{13} \mathrm{C}$ at control site which was characterized by high density and competition by trees. An increase in survivors tree-rings $\Delta^{13} \mathrm{C}$ probably indicates an improved water availability, possibly induced by a decrease in competition and in stand density or a decrease in the precipitation intercepted by the canopy (i.e., a stronger increase in $g$ over $A$ since a decrease in $A$ is highly unlikely). A change in foliar nitrogen, foliar $\Delta^{13} \mathrm{C}$ and content in chlorophylls was also recorded seven years after thinning.

- Thinnings carried out to convert old abandoned coppices into high-forest stands induce short-term stimulation of Turkey oak growth by increasing light and water availability. We were able to make a detailed reconstruction of the impact of past silvicultural treatment on the stand using a tree-ring wood $\Delta^{13} \mathrm{C}$ time-series.
\end{abstract}

Résumé - Le $\Delta^{13} \mathrm{C}$ des cernes révèle l'impact de la gestion forestière passée sur l'efficience d'utilisation de l'eau dans un taillis de chêne méditerranéen en Toscane (Italie).

- Les effets de l'éclaircie et de la réduction importante de la densité du peuplement ont été étudiés dans des forêts de chêne de Turquie (Quercus cerris L.) de l'Italie centrale, afin d'évaluer les réactions physiologiques et l'état de croissance des arbres qui ont survécu à une coupe de taillis et à une éclaircie pour la conversion du peuplement en futaie.

- L'hypothèse de travail était qu'une forte diminution de la densité du peuplement entraînerait une baisse de l'efficience intrinsèque d'utilisation de l'eau de la canopée (mesurée par le rapport de l'assimilation de $\mathrm{CO}_{2}$ à la conductance stomatique, $A / g$ ), donc par une augmentation de la discrimination isotopique du carbone dans les cernes $\left(\Delta^{13} \mathrm{C}\right)$.

- Les $\Delta^{13} \mathrm{C}$ des cernes des arbres restants («survivants ») ont été trouvés significativement $(P<$ $0,05)$ augmentés entre deux ans et sept ans après que le peuplement de taillis a été éclairci (conversion en futaie). Cet effet a été principalement causé par une importante diminution du $\Delta^{13} \mathrm{C}$ des cernes dans le peuplement témoin qui se caractérise par une forte densité et par une forte concurrence entre les arbres. Une augmentation de $\Delta^{13} \mathrm{C}$ dans les cernes des arbres survivants indique probablement une disponibilité en eau améliorée, induite peut-être par une diminution de la concurrence et de la densité du peuplement ou une diminution des précipitations interceptées par la canopée (par exemple, une augmentation très forte de $g$ au dessus de $A$ puisque une diminution de $A$ est hautement improbable). Un changement dans l'azote foliaire, le $\Delta^{13} \mathrm{C}$ foliaire et le contenu en chlorophylles ont également été enregistrés sept ans après l'éclaircie.

\footnotetext{
*Corresponding author: giovanni.dimatteo@entecra.it
} 
- Les éclaircies effectuées pour convertir les anciens taillis abandonnés en futaies induisent une stimulation à court terme de la croissance du chêne de Turquie en augmentant la lumière et la disponibilité en eau. Nous avons été en mesure de faire une reconstitution minutieuse de l'impact des traitements sylvicoles passés en utilisant des séries chronologiques temporelles de $\Delta^{13} \mathrm{C}$ du bois des cernes.

\section{INTRODUCTION}

Coppice forests are widely spread in temperate zone and markedly in Central and Southern Italy, where they were traditionally managed to provide wood for energy uses. Coppice forests characterize the mountain landscapes in Italy, and most broadleaf forests in Italy were coppiced for centuries. More recently, starting from the 1960s, due to the diffusion of fossil fuel, many coppice stands which had been regularly and intensively managed over centuries (see for example Fonti et al., 2006) were abandoned. Subsequently, many coppice stands, both State and privately owned, began to be converted into high-forests (Amorini et al., 1996), also due to the encouragement by the National Forest Service.

In spite of the wide diffusion of different methods to convert coppice to high forests (Amorini et al., 1996; Canellas et al., 2004; Ciancio et al., 2006; Giannini and Piussi, 1976), little is known about the physiological response of trees to thinning. Especially, it is of high relevance to investigate the impact of thinning on water-use efficiency, photosynthetic efficiency and tree growth in these regions of Italy where water availability is often limiting for plant productivity. Previously, only few studies have addressed the impact of silvicultural treatments on tree growth and physiology during and after the conversion of coppices into high-forest stands (Aussenac and Granier, 1988; Bréda et al., 1995; Cutini and Mascia, 1998).

Thinning is expected to improve the stand soil water availability because of decreased competition among trees due to decreased tree density and because of reduced amount of canopy-intercepted rainwater; hence, an increased stomatal conductance $(g)$ is also expected (McDowell et al., 2006) and this may affect photosynthetic $\mathrm{CO}_{2}$ assimilation $(A)$ and wateruse efficiency if soil water availability increases (Ripullone et al., 2009). This could explain the increased growth after thinning (Canellas et. al., 2004; Ducrey and Huc, 1999).

It is now well established that carbon isotope discrimination $(\Delta)$ in $C_{3}$ plants is correlated with the ratio of intercellular $(c i)$ and atmospheric concentrations of $\mathrm{CO}_{2}$ ( $\mathrm{ca}$ ) (Farquhar et al., 1982 ) and with intrinsic water use efficiency (iWUE). Therefore, any change in stomatal conductance and/or photosynthetic capacity reflected in changes in the ratio $c_{i} / c_{a}$ should be reflected in a change in the isotopic composition of the plant. This is why stable carbon isotope ratios in organic material have been widely used to assess plant response to changing environmental conditions. Especially in trees they have been mainly applied to study changes in water availability and water relations. Tree intrinsic water-use efficiency may be indirectly estimated through the analysis of $\Delta$ in plant biomass, through two independent relationships with $\mathrm{ci} / \mathrm{ca}$, (Farquhar et al., 1982). Hence, iWUE is defined as:

$$
\mathrm{iWUE}=A / g=c_{a}\left[1-\left(c_{i} / c_{a}\right)\right] 0.625
$$

where $A$ is the rate of net $\mathrm{CO}_{2}$ assimilation and $g$ is stomatal conductance of water. The carbon isotope composition of plant tissues $\left(\delta^{13} \mathrm{C}\right)$ reflects the environmental effects exerted upon $c_{i} / c_{a}$, hence it is strongly affected by any environmental parameter influencing stomatal conductance or photosynthetic capacity (Brugnoli and Farquhar, 2000). Especially, in trees changes in water availability among seasons should be recorded in the $\delta^{13} \mathrm{C}$ of the tree-ring. Previous reports have studied the response of carbon isotopic composition $\left(\delta^{13} \mathrm{C}\right)$ of leaves and wood to thinning in conifers (Leavitt and Long 1986; McDowell et al., 2006; Walcroft et al., 1996; Warren et al., 2001) and European beech (Fotelli et al., 2001; Gessler et al., 2001; Keitel et al., 2003).

Carbon isotope discrimination tree rings can be calculated as (Farquhar and Richards, 1984):

$$
\left[\Delta=\left(\delta^{13} C_{\text {air }}-\delta^{13} C_{\mathrm{p}}\right) /\left(1+\delta^{13} C_{\mathrm{p}}\right)\right]
$$

where $\delta^{13} \mathrm{C}_{\text {air }}$ is the isotopic composition of atmospheric $\mathrm{CO}_{2}$ and $\delta^{13} \mathrm{C}_{\mathrm{p}}$ is the isotopic composition of plant material. The advantage in using $\Delta^{13} \mathrm{C}$ instead of $\delta^{13} \mathrm{C}$ is that the former is independent of source air composition (i.e., atmospheric $\mathrm{CO}_{2}$ ).

Additional isotopic discrimination occurs along the pathway from photosynthates to wood, because of fractionation during secondary metabolism (see review by Brugnoli and Farquhar, 2000) and because of respiration of $\mathrm{CO}_{2}$ along the translocation from leaves to the trunk via phloem. Respired $\mathrm{CO}_{2}$ may be either refixed or it can diffuse back to the atmosphere, and during such processes there may be other fractionation processes (Cernusak et al., 2001). However, it can be assumed that such processes remain relatively constant among treatments and that differences in $\Delta^{13} \mathrm{C}$ observed were mostly due to changes in iWUE among treatments.

This study investigated the effects of silvicultural treatments (i.e., coppice cutting and heavy thinning) on tree-ring wood $\Delta{ }^{13} \mathrm{C}$ discrimination to elucidate the physiological and growth responses. The working hypothesis is that thinning had an impact on both foliar $\Delta^{13} \mathrm{C}$ and tree-ring $\Delta^{13} \mathrm{C}$. Furthermore, content in chlorophyll, foliar nitrogen were measured seven years after the thinning in order to elucidate whether there was an actual increase in comparisons to the control site.

\section{MATERIALS AND METHODS}

\subsection{Study area}

The study site is an oak (mainly Quercus cerris L.) coppice stand located at Poggio Pievano (430 $09 \mathrm{~N}, 10^{\circ} 54 \mathrm{E} ; 570 \mathrm{~m}$ a.s.1.), near Grosseto in the Maremma (Southern Tuscany, Italy). The stand had been coppiced approximately in the period between 1958 and 1960 and then abandoned for about $35 \mathrm{y}$ until 1995 when by thinning the stand was converted to high-forest. 
Table I. Dendrometical parameters measured before and soon after thinning to convert to high-forest (from Amorini et al., 1996a).

\begin{tabular}{lcccccc}
\hline & Survivors & \multicolumn{2}{c}{ Basal area } & \multicolumn{2}{c}{$\mathrm{d} g$} \\
\cline { 3 - 7 } & & Total & Q. cerris & F. ornus & Others \\
& $n$ ha $^{-1}$ & $\mathrm{~m}^{2} \mathrm{ha}^{-1}$ & $\%$ & $\%$ & $\%$ & $\mathrm{~cm}$ \\
\hline CCHF b.t. & 3181 & 33.22 & 92.70 & 2.7 & 4.7 & 11.5 \\
CCHF a.t. & 682 & 16.31 & 98.0 & 0.0 & 2.0 & 17.5 \\
\% removed & 79 & 51 & & & & \\
\hline
\end{tabular}

b.t. = Before thinning; a.t. $=$ after thinning.

Weather data were recorded at the meteorological station of Massa Marittima, located at $370 \mathrm{~m}$ a.s.1., $2 \mathrm{~km}$ from the study site (source: Ufficio Idrografico e Mareografico, Pisa) during the period 19801998. The area is characterized by mild Mediterranean climatic conditions. The annual mean temperature is $14.4{ }^{\circ} \mathrm{C}$ at the site, and mean annual precipitation is $906 \mathrm{~mm}$ distributed over $105 \mathrm{~d}$ of rain, with two maxima in autumn and spring. The absolute maximum temperature is $40.0{ }^{\circ} \mathrm{C}$, the absolute minimum temperature is $-10{ }^{\circ} \mathrm{C}$. No mean monthly temperature lower than $0{ }^{\circ} \mathrm{C}$ was observed, while for the periods January-March and November-December daily minimal temperatures were sometimes lower than $0{ }^{\circ} \mathrm{C}$. According to the Thornthwaite climatic classification system (Thornthwaite, 1948), the climate is humid, with moderate summer water deficit.

The abandoned coppice is an almost pure Turkey oak (Quercus cerris L.) stand ( $77.8 \%$ of the total number of resprouted stems and 92.7\% of the stand basal area). Fraxinus ornus L., Acer campestre L., Quercus ilex L. and Quercus pubescens Willd. are present in the understorey. The geological substrate comprises a silty clay schist ("marl") with siliceous chalks and to a lesser extent, calcareous sandstones (lower Cretaceous).

The experimental plot (total surface 0.5 ha) was selected to test two different methods of turkey oak coppice management: the first representing the natural evolution of a coppice (control site, $\mathrm{C}$ ), coppiced for the last time around the 1940s, and the second representing the evolution of a former coppice which was coppiced for the last time in 1958-1960, and then after about $35 \mathrm{y}$ the area was heavily thinned to convert it to high-forest (coppiced and converted to high forest site, CCHF). The CCHF site was an area containing original coppiced trees (resprouted by stumps soon after coppicing) dating back to 1958-1960 and heavily thinned after about 35 y (Tab. I, Amorini et al., 1996) to convert to high-forest (the coppice trees remaining after the thinning are known as "survivors"). There are also long-living trees, which germinated from seeds and were not cut by either coppicing or thinning ("standards").

\subsection{Sampling and sample preparation}

We sampled trees that were over $40 \mathrm{y}$ old at the control site to make tree-ring analyses in 2003 . We also took samples of the trees that had resprouted after coppicing from stumps and survived the thinning process (the "survivors") and long-living trees ("standards") from the CCHF site. Trees were sampled randomly at both sites.

In May 2003, 14 survivors and one standard were sampled at the $\mathrm{CCHF}$ site and 15 untreated trees at the $\mathrm{C}$ sites. We took two cores at breast height $(1.30 \mathrm{~m})$, in different sections of the stem, from each tree using an $0.5 \mathrm{~cm}$ diameter increment borer. Tree rings were dated with the help of a stereo microscope (Wild M3Z, Leica, Germany).
Ring-width measurements were made to the nearest $0.01 \mathrm{~mm}$, using time series analysis and presentation (TSAP) measurement equipment and software package (Frank Rinn, Heidelberg, Germany). The results were examined using the DENS software package (Swiss Federal Institute for Forest, Snow and Landscape Research, WSL, Birmensdorf, Switzerland). The raw ring-width series of the single cores were plotted, cross-dated visually and then cross-dated statistically by (i) the Gleichläufigkeit (interserial correlation), which is the percentage agreement in the signs of the first differences of two time series, and (ii) the Student's $t$-test which determines the degree of correlation between the curves. Annual tree-ring width was used to calculate the annual basal area increment ("BAI") for each tree. Only the best five cores that showed the highest coefficients of statistical significance due to the Gleichläufigkeit and Student's $t$-test at each site $(\mathrm{C}$ and $\mathrm{CCHF})$ were selected for isotopic analyses. We analysed the ${ }^{13} \mathrm{C} /{ }^{12} \mathrm{C}$ isotopic composition of each single tree-ring in three selected cores. Of the remaining two cores, only the single tree-rings formed six years prior to and seven years after the thinning were analysed.

\subsection{Foliar chlorophyll analysis}

In order to determine total chlorophyll $(a+b)$ content, in July 2002 we sampled the fully expanded sun leaves from the upper part of the crown in 15 dominant survivors at the CCHF site and in 15 dominant untreated trees in the $\mathrm{C}$ site seven years after the thinning. One sun leaf per tree was sampled (i.e. $n=15$ at the $\mathrm{C}$ site and $n=15$ at the CCHF site). After taking the samples, they were immediately sealed in cryovials and stored in a dark environment under liquid nitrogen and transported to the laboratory. Chlorophyll extraction was performed using 95\% Ethanol. The absorbance readings were taken in a spectrophotometer (Lambda 3B, Perkin Elmer, Norwalk, USA) at wavelengths of $664.2 \mathrm{~nm}$ and $648.6 \mathrm{~nm}$. The chlorophyll concentrations were calculated according to Lichtenthaler (1987).

\subsection{Isotopic analysis}

Whole wood (i.e., earlywood and latewood) from each single treering was split from the cores with a razor under a stereo microscope (40× magnification). Earlywood and latewood were not separated in the isotopic analyses as recent studies have shown that there is no difference between earlywood and latewood at an isotopic level (Borella and Leuenberger, 1998). The foliar carbon isotopic ratio was also analyzed in the same leaves used for chlorophyll and foliar nitrogen analyses in the CCHF and $\mathrm{C}$ sites. 
We ground the samples using a Retsch mill (Mixer Mills, MM 200, Haan, Germany). The resulting powder was weighed (approximately $1.5 \mathrm{mg}$ ) with a microbalance (Mettler AT 21 Comparator, Mettler Toledo AG, Greifensee, Switzerland) in tin capsules. Wood and foliar isotopic ratio was determined by combustion of the samples in an elemental analyser (Carlo Erba, model 1108EA, Milan, Italy) coupled to an isotopic ratio mass spectrometer (Finnigan MAT, model S delta, Bremen, Germany). Analysis precision was greater than $\pm 0.11 \%$. The results were expressed as delta $\left(\delta^{13} \mathrm{C}\right)$ in $\%$ o relative to the pee dee belemnite (PDB) standard where: $\left[\delta^{13} \mathrm{C}=\right.$ $\left.\left(R_{\text {sample }} / R_{\text {standard }}-1\right) \times 1000\right]$, where $R_{\text {sample }}$ and $R_{\text {standard }}$ represent the ${ }^{13} \mathrm{C} /{ }^{12} \mathrm{C}$ molar ratios of the sample and the standard respectively.

The wood and foliar isotope discrimination $\left(\Delta^{13} \mathrm{C}_{\text {wood leaf }}\right)$ was calculated according to Equation (2).

According to the Suess-effect (i.e., the decrease in $\delta^{13} \mathrm{C}$ value of air $\mathrm{CO}_{2}$ by about $1.5 \%$ due to fossil fuel burning), the atmospheric $\mathrm{CO}_{2}$ carbon isotopic composition values (i.e. $\delta^{13} \mathrm{C}_{\text {air }}$ ) used to calculate foliar (2002 y) and tree-ring isotopic discrimination chronologies (from 1920 to 2002 y) were extrapolated by recent works of Francey et al. (1999) and Robertson et al. (2001). Based on these data, we have recomputed the long term time course of tree-rings $\Delta^{13} \mathrm{C}$ values.

\subsection{Foliar nitrogen analysis}

The same leaves analysed for both chlorophyll and foliar $\Delta^{13} \mathrm{C}$ were used for the elemental nitrogen analysis. This powder was weighed (approximately $2.5 \mathrm{mg}$ ) with a microbalance (Mettler AT 21 Comparator, Mettler Toledo AG, Greifensee, Switzerland) in tin capsules. The foliar nitrogen content was determined by the combustion of samples in an elemental analyser (Carlo Erba, model 1108EA, Milan, Italy). The data were processed using Carlo Erba software and reported for each sample as percentage of dry weight.

\subsection{Statistics}

All statistical analyses were carried out using PRISM software version 4.01 (GraphPad Software, Inc. San Diego, CA, USA). We used variance analysis and pairwise $t$-test, null hypothesis of no significant difference in the mean tree-rings $\Delta^{13} \mathrm{C}$, chlorophyll, foliar nitrogen and BAI to establish the time period in which a significantly different response was observed in the control and the CCHF sites.

\section{RESULTS}

\subsection{Carbon isotopes responses after coppicing and thinning to convert to high-forest}

Carbon isotope discrimination in the CCHF site increased significantly after coppicing and after thinning in comparison with trees at $\mathrm{C}$.

Figure 1 shows the tree-ring isotope discrimination at the CCHF and at C sites for the period 1989 to 2002 only (i.e., six years before and seven years after the thinning). After the thinning, the mean $\Delta^{13} \mathrm{C}$ of "survivor" tree-rings from the $\mathrm{CCHF}$ site was higher $(19.30 \pm 0.21 \%$ ) than that of the tree-rings from the $\mathrm{C}$ site $(18.74 \pm 0.28 \%$ ). Significant differences were found for the years 1998 to 2002. However, this effect became

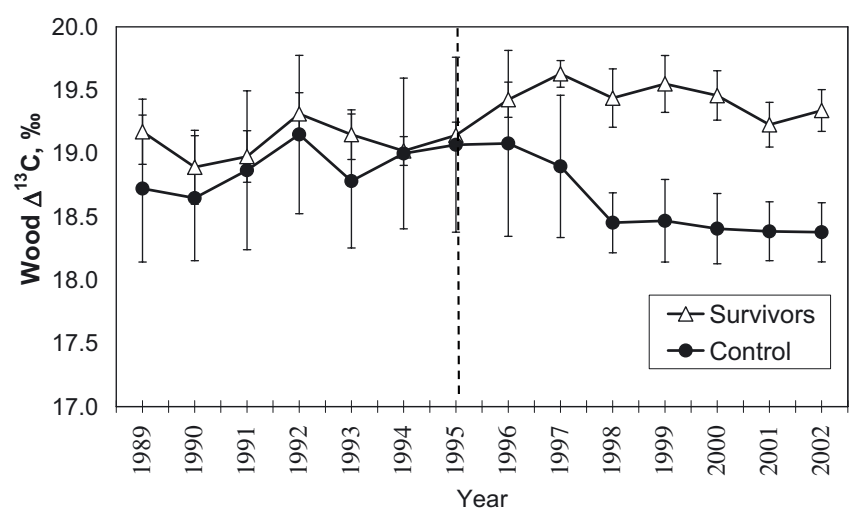

Figure 1. $\Delta^{13} \mathrm{C}$ trends measured for the $6 \mathrm{y}$ before and the $7 \mathrm{y}$ after thinning. Sample size was five at both the $\mathrm{CCHF}$ and the $\mathrm{C}$ sites. The figure shows the progressive $\Delta^{13} \mathrm{C}$ increase after the thinning (1995) when compared with $\Delta^{13} \mathrm{C}$ control site trends. Error bars indicate the standard error of the mean values. The dashed line indicates the date the forest was thinned to convert it to high forest.

significant only two years after the thinning and the $\Delta^{13} \mathrm{C}$ at the CCHF site was significantly different than that of the $\mathrm{C}$ site for at least 5 years after the thinning. This effect is probably due to a more decrease of tree-rings $\Delta^{13} \mathrm{C}$ in $\mathrm{C}$ site that to an increase of tree-rings $\Delta^{13} \mathrm{C}$ values in $\mathrm{CCHF}$ site. In fact significant differences in the long term time course in the two treatments was found from 1954 to 2002 y $(P<0.001$, paired $t$-test) with the mean tree-rings $\Delta^{13} \mathrm{C}$ values more less in the $\mathrm{C}$ site $(19.07 \pm 0.05)$ respect to the CCHF site $(19.43 \pm 0.04)$. Similarly, a significant $\Delta^{13} \mathrm{C}$ increase was only observed in the first three years after coppicing (Fig. 2). On the other hand, there was no significant difference between the two curves four years after coppicing, whereas no difference was found for two years after the thinning, and a significant difference was then clear for several years afterwards.

\subsection{Chlorophyll, foliar nitrogen and foliar $\Delta^{13} \mathrm{C}$ comparisons between the $\mathrm{CCHF}$ and the $\mathrm{C}$ sites}

Trees from the CCHF site were significantly higher in chlorophyll content, foliar nitrogen and foliar carbon discrimination values according to the tree-ring $\Delta^{13} \mathrm{C}$ values observed in 2002 (Tab. II). The mean chlorophyll value of the "survivors" (CCHF site) was $86.2 \pm 2.6 \mu \mathrm{g} \mathrm{cm}^{-2}$, whereas the trees at $\mathrm{C}$ sites showed a mean value of $80.8 \pm 2.5 \mu \mathrm{g} \mathrm{cm}^{-2}$.

\subsection{BAI responses after coppicing and thinning to convert to high-forest}

Average tree BAI (Basal Area Increment) strongly increased, especially after coppicing (Fig. 3). Before both coppicing and thinning, the BAI did not differ between the $\mathrm{C}$ site and the CCHF site $(P=0.85, P=0.92$ for coppice cut and thinning respectively, paired $t$-test), even though the increase seems to have begun before the coppicing event (1949), 


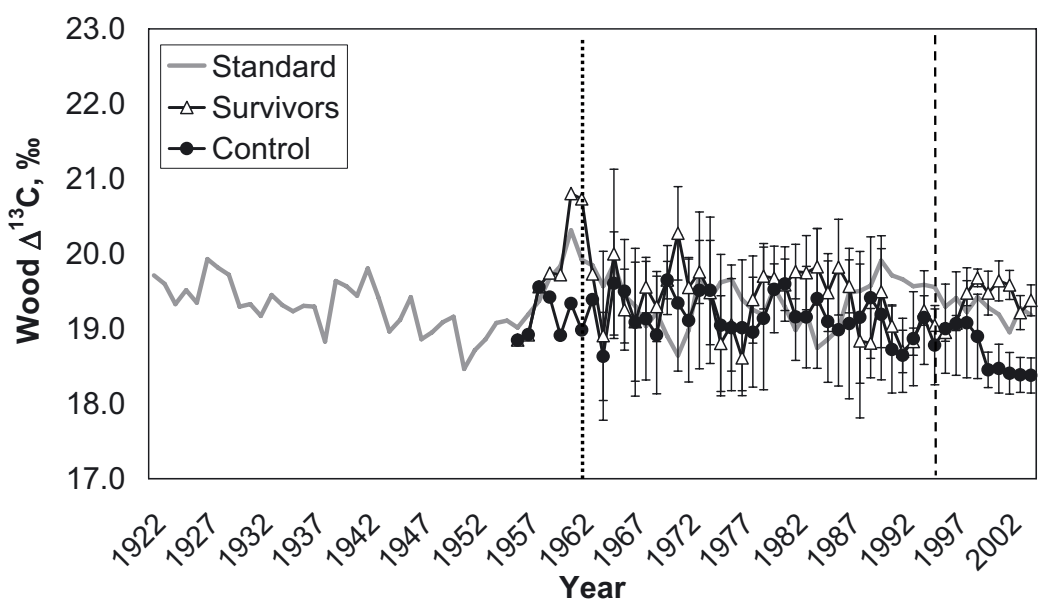

Figure 2. $\Delta^{13} \mathrm{C}$ trends of one "standard" (CCHF), "survivors" (CCHF) and untreated trees (C) respectively. Sample size was three at both the CCHF site and the $\mathrm{C}$ site. Increasing $\Delta^{13} \mathrm{C}$ trends were observed soon after the year the coppice was cut (approximately done in 1958-1960 y) and the year it was thinned (1995). Error bars indicate the standard error of the means. The dashed lines indicate the date the coppice was cut and the year it was thinned.

Table II. Foliar nitrogen, total chlorophyll, foliar $\Delta^{13} \mathrm{C}$ and tree-rings $\Delta^{13} \mathrm{C}$ mean value comparisons in both the $\mathrm{C}$ sites and the CCHF site seven years after thinning. The value in parentheses is the standard error of the mean. Statistical differences in the means were calculated with ANOVA.

\begin{tabular}{lcccc}
\hline & Nitrogen & Chlorophyll & Foliar $\Delta^{13} \mathrm{C}$ & Tree-rings $\Delta^{13} \mathrm{C}$ \\
& $\%$ & $\mu \mathrm{g} \mathrm{cm}^{-2}$ & $\%$ oo & $18.38(0.23)$ \\
\hline C-Control & $2.13(0.06)$ & $80.8(2.5)$ & $19.14(0.18)$ & $19.34(0.17)$ \\
CCHF-Survivors & $2.31(0.06)$ & $86.2(2.6)$ & $19.59(0.12)$ & 0.028 \\
$P$ value & 0.024 & 0.036 & 0.038 & 0.028 \\
\hline
\end{tabular}

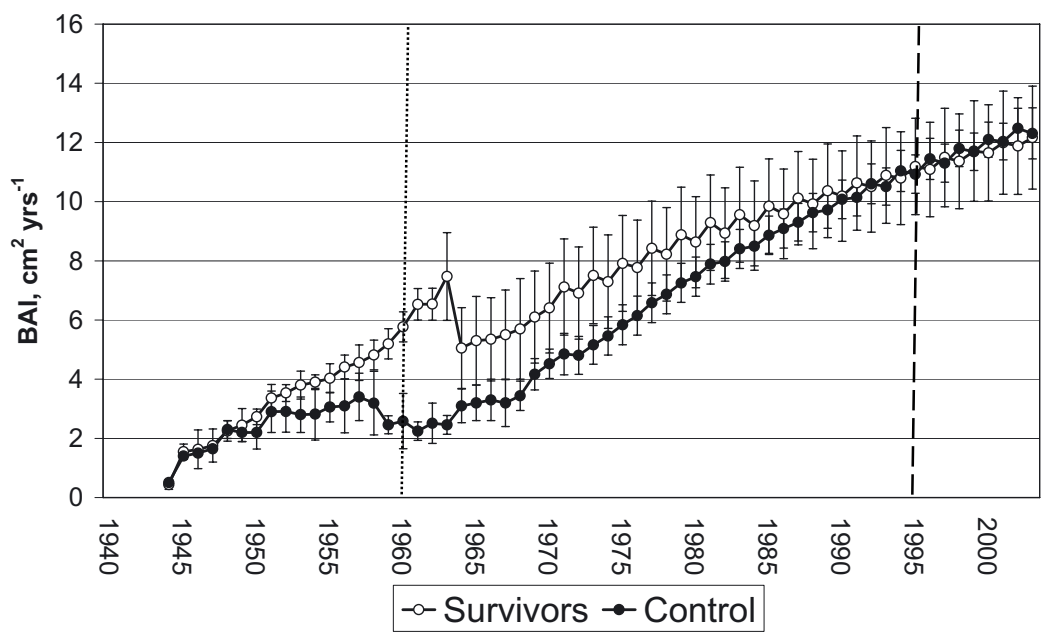

Figure 3. Basal Area Increment $\left(\mathrm{BAI}, \mathrm{cm}^{2}\right.$ ) in $\mathrm{C}$ site (filled circles) and in the CCHF site (open circles). Sample size was fifteen at both the $\mathrm{CCHF}$ site and $\mathrm{C}$ site. The dashed lines indicate the date the coppice was cut and thinned respectively. The error bars indicate the standard error of the means and the sample size was fifteen trees at each site. 
but increased dramatically in the first five years after coppicing $(P<0.001)$ whereas no increase was observed after thinning $(P=0.62)$ when the survivors were aged between about 35 to $42 \mathrm{y}$. At the CCHF site, the BAI value of "survivors" soon after coppicing increased from a mean BAI of $5.8 \mathrm{~cm}^{2}$ before coppicing to a peak value of $7.47 \mathrm{~cm}^{2}$ (increase of $40 \%$ ). Compared to both tree-ring $\Delta^{13} \mathrm{C}$ and BAI trends observed at $\mathrm{C}$ site, the growth response to coppicing was associated with significant increases in tree-ring $\Delta^{13} \mathrm{C}$ to a peak value in 1959 (20.80\%o). A large decrease in growth in the CCHF site only was observed during 1963-1964 associated with a significant parallel decrease in tree-ring $\Delta^{13} \mathrm{C}$. This was probably due to the fact that the canopy was rapidly restored due to the vigorous resprouting from stumps causing an increase in competition for water sources and nutrients.

Soon after coppicing, the $\Delta^{13} \mathrm{C}$ of "survivors" increased from 19.74 to $20.73 \%$, whereas no change in BAI occurred, although a significant increase in tree-ring $\Delta^{13} \mathrm{C}$ was observed seven years after thinning (from 18.95 to $19.38 \%$ ).

\section{DISCUSSION}

This study shown the response of the "survivors", which resprouted after the coppice cut (approximately done during 1958-1960 y) and survived the thinning to convert to highforest (which occurred in February 1995). The working hypothesis (i.e. that thinning had an impact on both tree-rings and foliar $\Delta^{13} \mathrm{C}$ ) was supported by the data. Compared with the control site, trend in tree-rings $\Delta^{13} \mathrm{C}$ at $\mathrm{CCHF}$ site increased after coppicing and thinning to convert the stand to high forest. Two-years delay after thinning the increase of tree-rings $\Delta^{13} \mathrm{C}$ became significant due to the evidence that carbohydrates assimilated during the previous year are present in the tree-ring of a given year (Fotelli et al., 2003; Geßler et al., 2001; Keitel et al., 2003; Skomarkova et al., 2006). The significant increase of survivors respect to trees in $\mathrm{C}$ site (albeit not robustly) may be explained by fact that tree-rings $\Delta^{13} \mathrm{C}$ trend in $\mathrm{C}$ site after thinning decrease while tree-rings $\Delta^{13} \mathrm{C}$ trend of survivors remained almost stable. This was because $\mathrm{C}$ site was characterized by high density and strong competition and could have suffered drought stress during those years while the survivors did not or did less due to the thinning. Ducrey and Huc (1999) studying 4 thinning intensities in coppices aged 43- and 57-years-old found that water stress was noticeably more severe in the case of the control compared to the thinned coppice. Aussenac and Granier (1988) in a Douglas fir plantations have observed that an increase of the soil water reserve led to a lower duration and level of water stress in the thinned plot. Same results were found also by Bréda et al. (1995) in a 43 year old Quercus petrea stand.

After coppicing a significant $\Delta^{13} \mathrm{C}$ increase was only observed in the first three years. This different reaction to both coppicing and thinning may be explained by the fact that the stand reacts differently to coppicing and to thinning. Compared to thinning, coppicing is major disturbance which dramatically decreases the leaf area index (LAI $=0)$, causing a sudden increase in irradiance for the remaining stools. It is only after many years (about 8) that a significant recovery in canopy characteristics occurs in the resprouted stems (Cutini, 2006). At the same time, heavy thinning could also result in larger gaps in the canopy leading to sudden isolation of the survivors. However Cutini found that five years after thinning the LAI and transmittance values were roughly the same as those of the control site.

The increased chlorophyll values after the thinning may be explained as an ecophysiological response to the sudden increase in radiation exposure (Björkman, 1981). This was probably due to the fact that thinning affects the canopies, increasing the percentage of gaps and thereby improving soil moisture conditions due to the reduced amount of rain intercepted by the canopy cover. This may also indicate that $\mathrm{C}$ site may be limited in nitrogen due to competition and this could lower chlorophyll content as well. This theory was confirmed by Makineci (2001) in a study carried out on Turkish oak coppices where total nitrogen amounts increased in top soil horizons after thinning. After thinning of Aleppo pine needles in South-Eastern Spain (Lopéz-Serrano et al., 2005) and old Ponderosa pine in Arizona (Wallin et al., 2004) it was found that foliar nitrogen concentration was higher where thinning had occurred. Improved soil water availability due to thinning was observed a few years after Douglas-fir thinning by Aussenac and Granier (1988) and by Stogsill et al. (1992) in loblolly pine plantations. Moreno and Cubera (2008) reported that thinning in Quercus ilex open woodlands reduces tree-to-tree competition and likely contributes to the improvement of tree water status and productivity in water-limited systems.

The BAI increase dramatically in the early five years after coppicing whereas no significant changes was observed after thinning probably due to the fact that when the stand was thinned (35 years old) the trees were old and had passed the culmination of current annual increment (Amorini and Fabbio, 2002). However in the Mediterranean region, the Turkey oak coppice rotation period was every $16 \mathrm{y}$ because the incremental effect induced by silvicultural treatments is evident only for short periods. The declining-senescent phase started after this rotation period.

\section{CONCLUSIONS}

In the Mediterranean region, forest policymakers promote the upgrading of abandoned old coppice woodlands to increase the environmental value and multifunctional role of forest stands. Heavy thinning to convert the coppice to high-forest may be an alternative way of coppice management to improve the stability, economic, landscape and ecological function of abandoned old coppices. This study demonstrated that silvicultural managements and especially thinning had an impact of both tree-ring and foliar $\Delta^{13} \mathrm{C}$, indicating that high forest conversion induces profound ecophysiological changes, at least in the short term.

The analysis of $\Delta^{13} \mathrm{C}$ indicate that the ratio of diffusive to biochemical limitations of photosynthesis clearly changed after thinning and, most likely this was attributable to increased 
conductance due to the likely improvement of soil water availability. This change between $\mathrm{C}$ and CCHF sites was accompanied by an increase in foliar nitrogen and foliar chlorophyll content. This may be related to changes in the radiation regime and especially in the light penetration in the canopy. However, the differences in foliar nitrogen between $\mathrm{CCHF}$ and $\mathrm{C}$ sites suggests that untreated trees in $\mathrm{C}$ site might be limited in nitrogen due to competition and higher stand density and this could contribute to lower leaf chlorophyll content. Treering $\Delta^{13} \mathrm{C}$ analyses showed higher discrimination values (i.e., lower intrinsic water-use efficiency) in CCHF site compared to the control stand. Higher $\Delta^{13} \mathrm{C}$ values most likely indicate higher stomatal conductance, which in turn means lower intrinsic water use-efficiency, and improved water availability. Indeed, a reduced assimilation rate and reduced photosynthetic capacity, which would also produce similar results on discrimination, are highly unlikely in this case, since the survivors in CCHF site showed higher $\mathrm{N}$ content and higher chlorophyll which eventually would point to increased photosynthesis per unit leaf area.

This result was also broadly demonstrated by Cutini and Mascia (1998) as they measured the daily patterns of stomatal conductance during the second and third year after thinning in a coppice stand in Southern Sardinia.

The analysis of tree-ring $\Delta^{13} \mathrm{C}$ trends in a long tree-ring series enabled us to assess the timing of the impact of coppicing. Both the tree-ring $\Delta^{13} \mathrm{C}$ series and the tree-ring dating of the "survivors" enabled us to reconstruct the exact year that coppicing took place. Forest management plans and previous studies (Amorini et al., 1996) reported that coppicing took place around 1960 in this area. Our data show that a significant increase of tree-ring $\Delta^{13} \mathrm{C}$ occurred in the years 1958-1961, and that the $\Delta^{13} \mathrm{C}$ values in the tree-rings had returned to insignificant levels by 1962 in the $\mathrm{C}$ site. Forest management plans usually report information on a forest-section scale. Such forest sections comprise several small plots and may have changed their borders over time, whereas coppicing may have been performed over areas crossing different forest sections. Thus, information from forest management plans may not be reliable when reconstructing past silvicultural treatment for a small-sized plot. On the other hand, treerings provide precious information on the impact of past forest management at a local scale.

Acknowledgements: We thank Gianfranco Fabbio, Emilio Amorini and Andrea Cutini (CRA-SEL, Arezzo) for their support during field sampling, Matilde Tamantini (Disafri, University of Viterbo) for the help with sample preparation, and Ermenegildo Magnani (Stable Isotopes Laboratory, Agrital Ricerche, Maccarese, Rome) for technical support with isotopic analysis. This study was supported by the Italian Ministry for Agricultural and Forest Policy, under the program Ri.Selv.Italia (Research unit 3.2.1, Disafri, University of Viterbo).

\section{REFERENCES}

Amorini E. and Fabbio G., 2002. Conversion to high forest and natural pattern into ageing Quercus cerris coppices. Results from 35 y of monitoring. The Caselli site (Tyrrhenian coast-Tuscany). Ann. Ist. Sper. Selv. 33: 79-104.
Amorini E., Bruschini S., Cutini A., Di Lorenzo M.G., and Fabbio G., 1996. Treatment of Turkey oak (Quercus cerris L.) coppices. Structure, biomass and silvicultural options. Ann. Ist. Sper. Selv. 27: $105-111$.

Aussenac G. and Granier A., 1988. Effects of thinning on water stress and growth in Douglas fir. Can. J. For. Res. 60: 100-105.

Björkman O., 1981. Responses to different quantum flux densities. In: Lange O.L., Nobel P.S., Osmond C.B., and Ziegler H. (Eds.), Encyclopedia of Plant Physiology: New Series, Springer Verlag, Berlin, Vol. 12: pp. 57-107.

Borella N. and Leuenberger M., 1998. Reducing uncertainties in d13C analysis of the tree rings: pooling, milling and cellulose extraction. J. Geogr. Res. 103: 19519-19526.

Bréda N., Granier A., and Aussenac G., 1995. Effects of thinning on soil water relations, transpiration and growth in an oak forest (Quercus petraea (Matt.) Liebl.). Tree Physiol. 15: 295-306.

Brugnoli E. and Farquhar G.D., 2000. Photosynthetic fractionation of carbon isotopes. In: Leegood R.C., Sharkey T.D., and von Caemmerer S. (Eds.), Photosynthesis: physiology and metabolism, Advances in Photosynthesis, Boston, Kluwer Academic Publishers, pp. 399-434.

Canellãs I., Del Rio M., Roig S., and Montero G., 2004. Growth response to thinning in Quercus pyrenaica Willd. coppice stands in Spanish central mountains. Ann. For. Sci. 61: 243-250.

Cernusak L.A., Marshall J.D., Comstock J.P., and Balster N.G., 2001. Carbon isotope discrimination in photosynthetic bark. Oecologia 128: 24-35.

Ciancio O., Corona P., Lamonaca A., Portoghesi L., and Travaglini D., 2006. Conversion of clearcut beech coppices into high forests with continuous cover: A case study in central Italy. For. Ecol. Manage. 224: $235-240$.

Cutini A., 2006. Coppice conversion cuts, coppicing and standards density: effects on canopy properties of Turkey oak coppice stands. Ann. Ist. Sper. Selv. 33: 21-30.

Cutini A. and Mascia V., 1998. Silvicultural treatment of holm oak (Quercus ilex L.) coppices in Southern Sardinia: effects of thinning on water potential, transpiration and stomatal conductance. Ann. Ist. Sper. Selv. 27: 47-53.

Ducrey M. and Huc R., 1999. Effects of thinning on growth and ecophysiology in an evergreen oak coppice. Rev. For. Fr. 51: 326-340.

Farquhar G.D. and Richard R.A., 1984. Isotopic composition of plant carbon correlates with water-use efficiency of wheat genotypes. Aust. J. Plant Physiol. 11: 539-552.

Farquhar G.D., O’ Leary M.H., and Berry J.A., 1982. On the relationship between carbon isotope discrimination and the intercellular carbon dioxide concentration in leaves. Aust. J. Plant Physiol. 9: 121-137.

Francey R.J., Allison C.E., Etheridge D.M., Trudinger C.M., Enting I.G., Leuenberger M., Langenfelds R.L., Michel E., and Steele L.P., 1999. A 1000 -year high precision record of $\delta^{13} \mathrm{C}$ in atmospheric $\mathrm{CO}_{2}$. Tellus 51B: 170-193.

Fonti P., Cherubini P., Rigling A., Weber P., and Biging G., 2006. Treerings show competition dynamics in abandoned Castanea sativa coppices after land-use changes. J. Veg. Sci. 17: 103-112.

Fotelli N.M., Rienks M., Rennemberg H., and Geßler A., 2003. Effect of climate and silvicultural on the carbon isotope composition of understorey species in a beech (Fagus sylvatica L.) forest. New Phytol. 159: 229-244.

Geßler A., Schrempp S., Matzarakis A., Mayer H., Rennemberg H., and Adams M.A., 2001. Radiation modifies the effect of water availability on the carbon isotope composition of beech (Fagus sylvatica L.). New Phytol. 150: 653-664.

Giannini R. and Piussi P., 1976. La conversion de taillis en futaie. L'expérience italienne. In: Proceedings XVI IUFRO World Congress, Oslo, Norway, pp. 388-396. 
Keitel C., Adams M.A., Holst T., Matzarakis A., Mayer H., Rennemberg H., and Geßler A., 2003. Carbon and Oxygen isotope composition of organic compounds in the phloem sap provides a short-term measure for stomatal conductance of European beech (Fagus Sylvatica L.). Plant Cell Environ. 26: 1157-1168.

Leavitt S.W. and Long A., 1986. Influence of site disturbance on $\delta^{13} \mathrm{C}$ isotopic time series from tree-rings. In: Proceedings of the International Symposium of Ecological Aspects of Tree-Ring Analysis, Tarrytown, New York, pp. 119-129.

Lichtenthaler H.K., 1987. Chlorophylls and carotenoids: pigments of photosynthetic apparatus biomembranes. Meth. Enzymol. 148: 349382.

Lopéz-Serrano F.R., Heras J. de Ias, Gonzalés-Ochoa A.I., and GarcìaMorota F.A., 2005. Effects of silvicultural treatments and seasonal patterns on foliar nutrients in young post-fire Pinus halepensis forest stands. For. Ecol. Manage. 210: 321-336.

Makineci E., 2001. Case studies on ecological effects of the improvement cuttings on coppice forests in Turkey. In: Proceedings Int. Conf. Forest Research: a challenge for an integrated European approach, Thessaloniki, Greece, 27 August-1 September 2001, Vol. I .

McDowell N., Henry D., Adams J., Bailey D., Marcey H., and Kolb T.E., 2006. Homeostatic Maintenance of Ponderosa Pine Gas Exchange in Response to stand density changes. Ecol. Appl. 16: 1164-1182.

Moreno G. and Cubera E., 2008. Impact of stand density on water status and leaf gas exchange in Quercus ilex. For. Ecol. Manage. 254: $74-84$.
Ripullone F., Guerrieri M.R., Saurer M., Siegwolf R., Jäggi M., Guarini R., and Magnani F., 2009. Testing a dual isotope model to track carbon and water gas exchanges in a Mediterranean forest. iForest 2: 59-66.

Robertson I., Waterhouse J.S., Barker A.C., Carter A.H.C., and Switsur V.R., 2001. Oxygen isotope ratios of oak in ast England:implications for reconstructing the isotopic composition of precipitation. Earth Planet. Sci. Lett. 191: 21-31.

Skomarkova M.V., Vaganov E.A., Mund M., Knohl A., Linke P., Boerner A., and Schulze E.D., 2006. Inter-annual and seasonal variability of radial growth, wood density and carbon isotope ratios in tree-rings of beech (Fagus sylvatica) growing in Germany and Italy. Trees 20: 571-586.

Stogsdill W.R., Wittwer R.F., Hennessey T.C., and Dougherty P.M., 1996. Water use in thinned loblolly pine plantations. For. Ecol. Manage. 50: 233-245.

Thornthwaite C.W., 1948. An approach toward a natural classification of climate. Geogr. Rev. 58: 55-94.

Walcroft S.A., Silvester W.B., Grace J.C., Carson S.D., and Waring R.H., (1996). Effects of branch length on carbon isotope discrimination in Pinus radiata. Tree Physiol. 16: 281-286.

Wallin K.F., Kolb T.E., Skov K.R., and Wagner M.R., 2004. Seven-year results of thinning and burning restoration treatments on old ponderosa pines at the Gus Pearson Natural Area. Rest. Ecol. 12: 239247.

Warren C.R., Mcgrath J.F., and Adams M.A., 2001. Water availability and carbon isotope discrimination in conifers. Oecologia 127: 476-486. 